KuLTura- мeDia- TeoLogia

ISSN 2081-8971

2017 nr 28, s. 9-23.

Jan Krupa*, Andrzej Mantaj**, Sławomir Gawroński*** *dr hab., Wydział Medyczny, Wyższa Szkoła Informatyki i Zarządzania w Rzeszowie, Katedra Turystyki i Rekreacji **dr, Wydział Administracji i Nauk Społecznych, Wyższa Szkoła Informatyki i Zarządzania w Rzeszowie, Katedra Metod Ilościowych w Ekonomii *** dr hab., Wydział Administracji i Nauk Społecznych, Wyższa Szkoła Informatyki i Zarządzania w Rzeszowie, Katedra Mediów, Dziennikarstwa i Komunikacji Społecznej

\title{
Ocena postrzegania mediów masowych jako źródła informacji w zakresie zdrowego stylu życia
} Evaluating the perception of mass media as a source of information of healthy lifestyles

\section{STRESZCZENIE:}

WSPÓŁCZEŚNIE MEDIA WYCHODZĄ NAPRZECIW ZAPOTRZEBOWANIU NA PROGRAMY DOTYCZĄCE ZDROWEGO STYLU ŻYCIA. MOŻNA SIĘ Z NICH DOWIEDZIEĆ, JAKĄ STOSOWAĆ DIETE, JAKĄ AKTYWNOŚĆ FIZYCZNĄ PRZEDSIĘWZIĄĆ, CZEGO UNIKAĆ, A DO CZEGO DAZŻYĆ. ŚRODKI MASOWEGO PRZEKAZU, W TYM GŁÓWNIE

INTERNET, TELEWIZJA I RADIO, PREZENTUJĄ CZĘSTO

WYSOKĄ WARTOŚĆ EDUKACYJNĄ I PROMOCYJNĄ

W ZAKRESIE DBAŁOŚCI O ZDROWIE, A ICH ZNACZENIE

WYNIKA Z OGÓLNODOSTĘPNOŚCI I POWSZECHNOŚCI, A TYM SAMYM MOŻLIWOŚCI SILNEGO ODDZIAŁYWANIA NA POZIOM WIEDZY I ŚWIADOMOŚĆ SPOŁECZNĄ.

PROBLEMEM PRZEDSTAWIONYM W ARTYKULE JEST IDENTYFIKACJA I OCENA OPINII RESPONDENTÓW W ZAKRESIE ROLI MEDIÓW JAKO ŹRÓDŁA INFORMACJI W KONTEKŚCIE KORZYSTNEGO DLA KONDYCJI ZDROWOTNEJ STYLU ŻYCIA. PRZEDMIOTEM BADAŃ BYŁA ANALIZA ODDZIAŁYWANIA RÓŻNYCH RODZAJÓW MEDIÓW

MASOWYCH, PODEJMUJĄCYCH TEMATYKĘ EDUKACJI I PROMOCJI ZDROWIA ORAZ STOPNIA ZAUFANIA RESPONDENTÓW WZGLĘDEM NICH. DLA REALIZACJI

\begin{abstract}
:
NOWADAYS MASS MEDIA RESPOND TO THE NEEDS OF HEALTHY LIFESTYLE PROGRAMS. YOU CAN FIND OUT THERE HOW TO APPLY A DIET, WHAT KIND OF PHYSICAL ACTIVITY TO TAKE, WHAT TO AVOID AND WHAT TO STRIVE FOR. MASS MEDIA, MAINLY THE INTERNET, TELEVISION AND RADIO, OFFER HIGH VALUE OF EDUCATIONAL AND HEALTH PROMOTION IN THE FIELD OF PUBLIC HEALTH. THEY ARE IMPORTANT BECAUSE THEY ARE PUBLIC AND UNIVERSAL, AND THUS HAVE A STRONG IMPACT ON THE LEVEL OF KNOWLEDGE AND SOCIAL AWARENESS.

THE PROBLEM PRESENTED IN THE ARTICLE IS THE IDENTIFICATION AND EVALUATION OF RESPONDENTS' OPINIONS ABOUT THE ROLE OF THE MEDIA AS A SOURCE OF INFORMATION IN THE CONTEXT OF A HEALTHY LIFESTYLE. THE SUBJECT OF THE STUDY WAS AN ANALYSIS OF THE INFLUENCE OF DIFFERENT TYPES OF MASS MEDIA ON EDUCATION AND HEALTH PROMOTION. THE METHOD OF THE DIAGNOSTIC SURVEY ON THE GROUP OF RESPONDENTS FROM THE AREA OF TARNÓW WAS USED IN THE STUDY. THE ANALYSIS OF THE TEST
\end{abstract}


ZAŁOŻONEGO CELU POSŁUŻONO SIĘ METODĄ SONDAŻU DIAGNOSTYCZNEGO W ZAKRESIE POZYSKIWANIA PRZEZ RESPONDENTÓW INFORMACJI O ZDROWIU ZA POŚREDNICTWEM MEDIÓW, SKUTECZNOŚCI ODDZIAŁYWANIA TYCH INFORMACJI ORAZ STOPNIA ICH WYKORZYSTANIA PRZEZ GRUPĘ RESPONDENTÓW Z TERENU POWIATU TARNOWSKIEGO. ANALIZE WYNIKÓW BADAŃ PRZEPROWADZONO W OPARCIU O STATYSTYKE TESTU KRUSKALA-WALLISA.

NAJBARDZIEJ WYRAŹNE ZWIĄZKI W POWYŻSZYM ZAKRESIE STWIERDZONO WZGLĘDEM INTERNETU I FORÓW INTERNETOWYCH, NA KTÓRE JAKO NAJWAŻNIEJSZE WSKAZYWAŁY OSOBY MŁODSZE, KOBIETY, MIESZKAŃCY WSI I MNIEJSZYCH MIAST ORAZ OSOBY Z WYŻSZYM WYKSZTAŁCENIEM. PRASĘ, JAKO ŹRÓDŁO INFORMACJI O KORZYSTNYM DLA KONDYCJI ZDROWOTNEJ STYLU ŻYCIA, PRZEDKŁADALI RESPONDENCI STARSI, MĘŻCZYŹNI, OSOBY Z WYKSZTAŁCENIEM WYŻSZYM I ŚREDNIM ORAZ MIESZKAŃCY WSI. Z KOLEI, JAKOŚĆ I PRZYDATNOŚĆ PRZEKAZYWANYCH PRZEZ MASS MEDIA INFORMACJI DOTYCZĄCYCH TEJ PROBLEMATYKI NAJWYŻEJ CENIŁY SOBIE OSOBY MŁODSZE, MIESZKAŃCY WSI I MNIEJSZYCH MIAST ORAZ ABSOLWENCI SZKÓŁ WYŻSZYCH.

\section{SŁOWA KLUCZOWE:}

MEDIA MASOWE, EDUKACJA I PROMOCJA ZDROWIA, KOMUNIKOWANIE O ZDROWIU, BADANIA ANKIETOWE
RESULTS WAS BASED ON KRUSKAL-WALLIS STATISTICS. THE LARGEST RELATIONSHIPS IN THIS AREA WERE FOUND WITH REGARD TO THE INTERNET AND ONLINE FORUMS, WHICH WERE THE MOST IMPORTANT FOR YOUNGER PEOPLE, WOMEN, RURAL CITIZENS, AND PEOPLE WITH HIGHER EDUCATION LEVEL. AS A SOURCE OF INFORMATION ON HEALTH-PROMOTING LIFESTYLES, THE MEN, EDUCATED PEOPLE, MIDDLE-AGED AND RURAL RESIDENTS WERE REPORTED BY THE PRESS. ON THE OTHER HAND, THE QUALITY AND USEFULNESS OF THE INFORMATION PROVIDED BY THE MASS MEDIA CONCERNING THIS ISSUE WAS MOST APPRECIATED BY YOUNGER PEOPLE, RURAL AND SMALLER TOWN CITIZENS AS WELL AS UNIVERSITY GRADUATES.

\section{KEYWORDS:}

MASS MEDIA, EDUCATION AND HEALTH PROMOTION, HEALTH COMMUNICATION, SURVEY STUDY

$\mathrm{D}$ zięki szybkiemu rozwojowi techniki, problematyka promocji zdrowia stała się jednym z ważnych elementów oddziaływania na społeczeństwo, stając się istotnym źródłem wiadomości w tym zakresie. Popularne media masowe wywierają silny wpływ edukacyjny na zdrowie publiczne, będące znaczącym czynnikiem funkcjonowania każdego państwa [Turbiasz, Kadłubowska, Kolonko i Bąk, 2010].

Celem niniejszego opracowania jest identyfikacja i ocena opinii respondentów w zakresie znaczenia mediów jako źródła informacji o korzystnym dla kondycji zdrowotnej stylu życia. Przedmiotem badań była analiza oddziaływania różnych rodzajów mediów podejmujących powyższą tematykę oraz stopnia zaufania respondentów względem nich.

\section{Media masowe i komunikowanie o zdrowiu}

Nigdy w dziejach ludzkości człowiek czy grupy społeczne nie dysponowały równie bogatym arsenałem środków komunikowania, jak obecnie [Goban-Klas, 2002]. Media maso- 
we to jeden z kluczowych pośredników w rozpowszechnianiu informacji i jedno z najbardziej efektywnych narzędzi promocji. Zapewniają one dotarcie z przekazem zarówno do szerokiego kręgu odbiorców, jak i do odbiorcy sprofilowanego, adekwatnego do tematyki, treści oraz charakteru nadawanego komunikatu. Istotą informacji docierającej do adresatów za sprawą mediów jest przypisywana jej wiarygodność, zaufanie i obiektywność, a przez to siła oddziaływania. Stąd, niezbędna jest także umiejętność ich właściwego i skutecznego wykorzystania w programach edukacji zdrowotnej i promocji zdrowia.

Media masowe pełnią cztery podstawowe funkcje: informacyjną, opiniotwórczą, wychowawczą i edukacyjną. Owe cztery zasadnicze funkcje odgrywają istotną rolę w zakresie komunikowania o zdrowiu, procesach związanych z promocją zdrowego stylu życia i kształtowaniem zachowań prozdrowotnych wśród odbiorców. Środki masowego komunikowania są jednym z narzędzi kreowania rynku, $w$ tym propagowania zdrowego stylu życia, aktualnej mody, ale również w spełnianiu innych zróżnicowanych oczekiwań odbiorców. Mają one również bardzo duży wpływ na nasz światopogląd i postawy życiowe.

Intensywny rozwój technologii, ale również dostępność środków masowego przekazu takich, jak: telewizja, Internet, codzienna prasa, stały się nieodzownym elementem życia współczesnego człowieka. Ta wszechobecność mediów nie tylko wpływa na organizację życia każdego z nas, ale całego społeczeństwa, prowadząc również do zmian w sferze intelektualnej czy społecznej [Turbiasz, Kadłubowska, Kolonko i Bąk, 2010].

Wszechobecna reklama w środkach masowego przekazu posiada ogromny wpływ na kształtowanie zachowań zdrowotnych. Wiadomo, jak istotną rolę w życiu odgrywa właściwa dieta. Branża reklamowa zdaje sobie z tego doskonale sprawę i dlatego pośród promowanych produktów artykuły spożywcze i suplementy diety zajmują jedną z najważniejszych pozycji.

\section{Metody badań i materiał empiryczny}

Dla realizacji założonego celu posłużono się metodą sondażu diagnostycznego, przy pomocy techniki ankietowej. Narzędziem badawczym był autorski kwestionariusz ankiety, zawierający 25 zamkniętych pytań dotyczących pozyskiwania informacji o zdrowiu poprzez media, skuteczności oddziaływania tych informacji na odbiorcę oraz stopnia ich wykorzystania przez grupę respondentów. Ze względu na jakościowy charakter zmiennych do analizy ich powiązań posłużono się statystyką testu Kruskala-Wallisa.

Materiał empiryczny stanowiły wyniki 114 losowych wywiadów ankietowych, przeprowadzonych w roku 2015 na terenie powiatu tarnowskiego, w województwie małopolskim. Ogólną charakterystykę ankietowanych osób ze względu na wybrane cechy zebrano w tabeli 1 . Osoby w wieku poniżej 40 lat stanowiły ok. 56\%, a starsze $44 \%$ badanych. Z kolei udział kobiet w próbie wynosił prawie $60 \%$, a mężczyzn ok. $40 \%$. 
Tabela 1. Respondenci z uwagi na wybrane zmienne

\begin{tabular}{|l|l|l|}
\hline \multicolumn{2}{|l|}{ Kryterium podziału respondentów } & Liczba \\
\hline Wiek & $18-40$ & 64 \\
\hline & $>40$ & 50 \\
\hline Płeć & Kobiety & 68 \\
\hline & Mężczyźni & 46 \\
\hline Miejsce zamieszkania & Wieś & 32 \\
\hline & miasto do 50 tys. mieszkańców & 44 \\
\hline & miasto pow. 50 tys. mieszkańców & 38 \\
\hline Wykształcenie & Zawodowe & 37 \\
\hline & Średnie & 42 \\
\hline & Wyższe & 35 \\
\hline
\end{tabular}

Źródło: badania własne

Najwięcej respondentów pochodziło z miast liczących poniżej 50 tys. mieszkańców $(38,60 \%)$, następnie z miast większych $(33,33 \%)$, a pozostałe osoby były mieszkańcami wsi $(28,07 \%)$. Około $37 \%$ ankietowanych posiadało wykształcenie średnie, $32 \%$ - zawodowe, a pozostali deklarowali wykształcenie wyższe. Ogólnie można więc stwierdzić, że rozkład liczby osób ze względu na powyższe charakterystyki był w miarę wyrównany.

Wszystkie uwzględnione w badaniach opinie wyrażano w skali od 1 do 5 punktów, a więc były mierzone na skali porządkowej, przy czym wartość najmniejsza oznacza zawsze najniższy stopień akceptacji kwestii będącej przedmiotem pytania. Odpowiedzi te analizowano na tle wieku, płci, wielkości zamieszkiwanej miejscowości oraz wykształcenia badanych osób, jako determinant oceny roli mediów jako źródła informacji dotyczących zdrowego stylu życia. Uwzględnione w badaniach cechy są zgodne z najczęściej branymi pod uwagę w podobnych sytuacjach, charakterystykami analizowanych w niniejszej pracy zjawisk [Gugała, Boratyn-Dubiel i Chmiel, 2010], [Szymczuk, Zajchowska, Dominik, Makara-Studzińska, Zwolak i Daniluk, 2011], [Syrkiewicz- Świtała, Holecki, Wojtynek, 2014].

Porządkowy charakter zmiennych objaśnianych spowodował, że zdecydowano się na analizę istotności różnic między ich wielkościami na tle wydzielonych podgrup ankietowanych. Biorąc za podstawę podziału respondentów płeć oraz wiek, podzielono ich na dwie podgrupy, natomiast z uwagi na wielkość miejsca zamieszkania i wykształcenie wyodrębniono trzy podgrupy osób. W przypadku stwierdzenia statystycznie istotnych różnic wielkości zmiennych objaśnianych między wydzielonymi podgrupami ankietowanych, można było wnosić o powiązaniach tych zmiennych z ich determinantami, czyli cechami stanowiącymi kryteria podziału.

Do oceny istotności zróżnicowania poziomu zmiennych wykorzystano statystykę testu Kruskala-Wallisa oraz, wyznaczoną na podstawie statystyki $x^{2}$, wartość krytyczną najmniejszej istotnej różnicy [Aczel, 2000].

Przed przystąpieniem do stosowania statystyki testu Kruskala-Wallisa zakładano hipotezę zerową, że rozpatrywane populacje posiadają takie same rozkłady. Sprowadza się to do stwierdzenia jednakowego położenia populacji, a na odchylenia od tego założenia test Kruskala-Wallisa jest szczególnie wrażliwy. Stosowanie tego testu wymaga opisu 


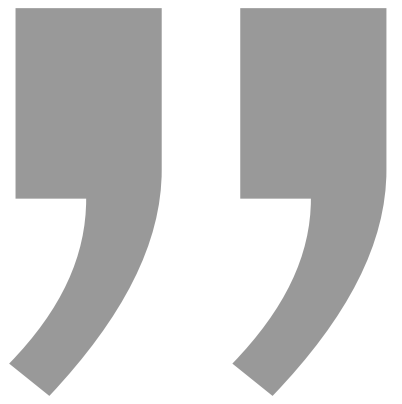

Wszechobecna reklama

w środkach masowego przekazu posiada

ogromny wpływ na kształtowanie

zachowań zdrowotnych.

Wiadomo, jak istotną rolę w życiu odgrywa

właściwa dieta. Branża reklamowa

zdaje sobie z tego doskonale sprawę

i dlatego pośród promowanych produktów

artykuły spożywcze i suplementy diety

zajmują jedną z najważniejszych pozycji.

badanych zmiennych, co najmniej na skali porządkowej, które to kryterium jest przez dane uwzględnione $\mathrm{w}$ analizie spełnione. Statystyczne hipotezy zerowe, przy założeniu ich prawdziwości, odrzucano, przyjmując poziom istotności $\alpha=0,05$.

\section{Wyniki badań i ich omówienie}

Wiek respondentów a ich opinie o roli mediów jako źródła informacji w zakresie zdrowego stylu życia Jako pierwsze kryterium statystycznej analizy uwarunkowań oceny mediów jako źródła informacji dotyczących zdrowego stylu życia przyjęto wiek respondentów (tab. 2). Na wstępie rozważona zostanie siła oddziaływania mediów w powyższym zakresie. Jak się okazuje, osoby młodsze w sposób statystycznie silnie istotny większą rolę przypisywały Internetowi, natomiast starsze prasie i radiu. Wiąże się to zapewne z częstością kontaktu obu grup respondentów z poszczególnymi rodzajami mediów, co wynika także z potrzeby posiadania pewnych umiejętności przy korzystaniu z Internetu, którymi w wyższym stopniu dysponowały osoby młodsze.

Kolejnym badanym zjawiskiem był stopień zaufania do informacji zawartych w mediach i tyczących rozważanych zagadnień. Otóż znamienne jest to, że osoby młodsze wykazały w sposób statystycznie istotny większe zaufanie do zasobów Internetu, a osoby starsze bardziej zawierzały telewizji i radiu. Wiąże się to zapewne z wyższym stopniem korzystania przez osoby młodsze z Internetu i możliwością bardziej wybiórczego, w porównaniu z pozostałymi mediami, poszukiwania w nim informacji. Należy zwrócić uwagę także na fakt, że osoby młodsze wykazały w sposób statystycznie istotny wyższą tolerancję możliwości wystąpienia złych skutków korzystania z wiedzy prezentowanej w Internecie, aczkolwiek z drugiej strony większa w tym zakresie krytyczność osób starszych, mających rzadszy kontakt z tym środkiem przekazu, wskazywać może na nieco inne podłoże tej postawy. 
Tabela 2. Wiek respondentów a ich opinie o stopniu oddziaływania i zaufania do mediów w zakresie upowszechniania zdrowego stylu życia

\begin{tabular}{|c|c|c|c|}
\hline \multirow[t]{2}{*}{ Opinie respondentów względem mediów } & \multicolumn{2}{|c|}{$\begin{array}{l}\text { Średnie rangi dla opinii } \\
\text { wśród respondentów }\end{array}$} & \multirow{2}{*}{$\begin{array}{l}\text { Ocena różnic rang } \\
\text { między grupami } \\
\text { respondentów }\end{array}$} \\
\hline & młodszych & starszych & \\
\hline \multicolumn{4}{|l|}{ Siła promocyjnego oddziaływania mediów: } \\
\hline - Internetu & 76,8 & 32,8 & $0,00^{* *}$ \\
\hline - telewizji & 58,4 & 56,4 & 0,73 \\
\hline - prasy & 37,3 & 83,3 & $0,00^{* *}$ \\
\hline - radia & 48,9 & 68,5 & $0,00^{* *}$ \\
\hline \multicolumn{4}{|l|}{ Stopień zaufania wg rodzajów mediów: } \\
\hline - Internet & 76,6 & 33,1 & $0,00^{* *}$ \\
\hline \begin{tabular}{|l|} 
- możliwość wystąpienia złych skutków \\
wykorzystania wiedzy uzyskanej poprzez Internet
\end{tabular} & 43,5 & 75,4 & $0,00^{* *}$ \\
\hline - telewizja & 45,7 & 72,6 & $0,00^{* *}$ \\
\hline - radio & 47,9 & 69,7 & $0,00^{* *}$ \\
\hline Media a jakość informacji & 66,5 & 46,0 & $0,00^{* *}$ \\
\hline Media a przydatność informacji & 65,3 & 47,5 & $0,00^{* *}$ \\
\hline $\begin{array}{l}\text { Wystarczalność liczby prozdrowotnych kampanii } \\
\text { społecznych }\end{array}$ & 76,0 & 33,8 & $0,00^{* *}$ \\
\hline \multicolumn{4}{|l|}{ Częstość korzystania z porad w mediach: } \\
\hline - Internetu & 73,9 & 36,5 & $0,00^{* *}$ \\
\hline - for internetowych & 74,0 & 36,4 & $0,00^{* *}$ \\
\hline - telewizji & 66,1 & 46,5 & $0,00^{* *}$ \\
\hline - prasy & 54,0 & 62,0 & 0,17 \\
\hline $\begin{array}{l}\text { Korzystanie z porad w mediach przez osoby } \\
\text { z najbliższego otoczenia }\end{array}$ & 65,4 & 47,6 & $0,00^{* *}$ \\
\hline
\end{tabular}

istotność przy prawdopodobieństwie $\mathrm{p}=0,05$ / significanceat $\mathrm{p}=0.05$ probability

** - istotność przy prawdopodobieństwie $\mathrm{p}=0,01$ / significanceat $\mathrm{p}=0,01$ probability

\section{Źródło: Obliczenia własne}

Następnym aspektem badań była opinia respondentów dotycząca jakości i przydatności informacji zawartych w mediach. W tym przypadku ocena osób młodszych była w sposób statystycznie silnie istotny wyższa od wyrażanej przez osoby starsze. Podobna relacja między opiniami wystąpiła w przypadku wystarczalności liczby prozdrowotnych kampanii społecznych, co mogło także wynikać z ograniczonego dostępu osób starszych do bardziej wszechstronnego źródła informacji, jakim jest Internet.

Na tle powyższych opinii można przeanalizować rozkłady liczebności respondentów korzystających z porad zamieszczanych w mediach. Wykazały one w sposób statystycznie silnie istotny większe zainteresowanie osób młodszych Internetem, forami internetowymi, jak i telewizją. Osoby starsze, co prawda sięgały nieco częściej po prasę, ale względem osób młodszych różnica ta nie wykazała statystycznej istotności. Swoistą pra- 


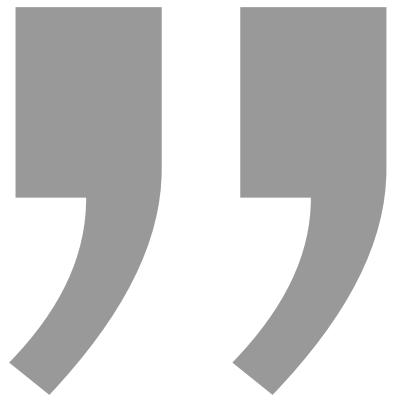

Na tle powyższych opinii można przeanalizować rozkłady liczebności respondentów korzystających z porad zamieszczanych w mediach. Wykazały one w sposób statystycznie silnie istotny większe zainteresowanie osób młodszych Internetem, forami internetowymi, jak i telewizja. Osoby starsze, co prawda sięgały nieco częściej po prasę, ale względem osób młodszych różnica ta nie wykazała statystycznej istotności. Swoistą prawidłowością jest fakt, że szersze zainteresowanie poradami prozdrowotnymi w mediach wykazywało otoczenie osób młodszych, którym przede wszystkim sieć komputerowa umożliwia szybszy i szerszy kontakt między soba.

widłowością jest fakt, że szersze zainteresowanie poradami prozdrowotnymi w mediach wykazywało otoczenie osób młodszych, którym przede wszystkim sieć komputerowa umożliwia szybszy i szerszy kontakt między sobą.

Ogólnie można stwierdzić, że osoby młodsze korzystały częściej z porad przedstawianych przez media, przedkładając w tym względzie telewizję oraz Internet, przy czym ten ostatni darzyły także większym zaufaniem, aniżeli osoby starsze.

\section{Płeć respondentów a ich opinie o roli mediów jako źródła informacji w zakresie zdrowego stylu życia}

Za drugie kryterium statystycznej analizy uwarunkowań ocen mediów jako źródła informacji dotyczących zdrowego stylu życia, przyjęto płeć respondentów (tab. 3). Podobnie jak powyżej, analizę rozpoczęto od statystycznej weryfikacji różnic opinii dotyczących oddziaływania mediów w tym zakresie. Otóż okazało się, że kobiety przypisywały statystycznie udowodnione i większe znaczenie Internetowi, aniżeli mężczyźni, a ci z kolei mocniej wyróżniali prasę oraz radio, co mogło wynikać także z odmiennego trybu życia osób różnej płci. Nie różniły się one jednak pod względem opinii dotyczących siły oddziaływania telewizji. 
Tabela 3. Płeć respondentów a ich opinie o stopniu oddziaływania i zaufania do mediów w zakresie upowszechniania zdrowego stylu życia

\begin{tabular}{|c|c|c|c|}
\hline \multirow[t]{2}{*}{ Opinie respondentów względem mediów } & \multicolumn{2}{|c|}{$\begin{array}{l}\text { Średnie rangi dla } \\
\text { opinii wśród } \\
\text { respondentów }\end{array}$} & \multirow[t]{2}{*}{$\begin{array}{l}\text { Ocena różnic rang } \\
\text { między grupami } \\
\text { respondentów }\end{array}$} \\
\hline & kobiety & mężczyźni & \\
\hline \multicolumn{4}{|l|}{ Siła promocyjnego oddziaływania mediów: } \\
\hline - Internetu & 62,8 & 49,7 & $0,03^{*}$ \\
\hline - telewizji & 58,9 & 55,4 & 0,53 \\
\hline - prasy & 51,7 & 66,1 & $0,02^{*}$ \\
\hline - radia & 52,3 & 65,2 & $0,03^{*}$ \\
\hline \multicolumn{4}{|l|}{ Stopień zaufania do mediów wg ich rodzajów: } \\
\hline - Internet & 61,0 & 52,3 & 0,14 \\
\hline $\begin{array}{l}\text { - możliwość wystąpienia złych skutków } \\
\text { wykorzystania wiedzy uzyskanej poprzez Internet }\end{array}$ & 59,1 & 55,2 & 0,52 \\
\hline - telewizja & 52,1 & 65,5 & $0,02^{*}$ \\
\hline - radio & 52,1 & 65,5 & $0,03^{*}$ \\
\hline Media a jakość informacji & 56,3 & 59,3 & 0,60 \\
\hline Media a przydatność informacji & 59,6 & 54,4 & 0,33 \\
\hline $\begin{array}{l}\text { Wystarczalność liczby prozdrowotnych kampanii } \\
\text { społecznych }\end{array}$ & 55,7 & 60,2 & 0,43 \\
\hline \multicolumn{4}{|l|}{ Częstość korzystania z porad w mediach: } \\
\hline - Internetu & 60,6 & 52,9 & 0,21 \\
\hline - for internetowych & 66,3 & 49,0 & $0,02^{*}$ \\
\hline - telewizji & 62,4 & 50,3 & $0,03^{*}$ \\
\hline - prasy & 55,8 & 60,1 & 0,47 \\
\hline $\begin{array}{l}\text { Korzystanie z porad w mediach przez osoby } \\
\text { z najbliższego otoczenia }\end{array}$ & 60,1 & 53,7 & 0,27 \\
\hline
\end{tabular}

istotność przy prawdopodobieństwie $\mathrm{p}=0,05$

** - istotność przy prawdopodobieństwie $\mathrm{p}=0,01$

\section{Źródło: Obliczenia własne}

Pod względem zaufania do mediów wystąpiły tylko dwie statystycznie istotne różnice, tj. mężczyźni zawierzali bardziej telewizji i radiu, niż kobiety. Stopień zaufania do Internetu oraz ocena możliwych negatywnych skutków wykorzystania wiedzy uzyskanej poprzez Internet były w obu tych grupach osób podobne. Zbliżone też były ich opinie dotyczące jakości i przydatności informacji zawartych w mediach oraz wystarczalności liczby prozdrowotnych kampanii społecznych.

Z kolei biorąc pod uwagę częstości korzystających z porad zawartych w mediach, stwierdzić można, że w sposób statystycznie silnie istotny większe zainteresowanie forami internetowymi oraz telewizją wykazały kobiety, natomiast korzystanie z Internetu i prasy nie różnicowało obu płci. Podobne też było, w obu tych grupach osób, korzystanie z porad w mediach przez osoby z ich najbliższego otoczenia. Ogólnie można stwier- 
dzić, że wyższy stopień zawierzenia przez mężczyzn niektórym rodzajom mediów nie znalazł swego odzwierciedlenia w stopniu korzystaniu z nich.

\section{Miejsce zamieszkania respondentów a ich opinie o roli mediów jako źródła informacji w zakresie zdrowego stylu życia}

Jako trzecią podstawę statystycznej analizy ocen mediów jako źródła informacji dotyczących zdrowego stylu życia przyjęto miejsce zamieszkania respondentów, których podzielono na mieszkańców wsi oraz miast liczących do i powyżej 50 tys. osób (tab. 4). Rozważając powyższe oddziaływanie mediów okazało się, że w przypadku Internetu najsilniej ich wpływ podkreślali mieszkańcy małych miast, a następnie wsi, przy czym opinie tych dwóch grup osób różniły się w sposób statystycznie istotny od tych poglądów panujących w dużych miastach. Na wagę oddziaływania telewizji spośród rozważanych trzech grup respondentów najczęściej wskazywali mieszkańcy wsi, a największe znaczenie promocyjne prasie i radiu przypisywali mieszkańcy dużych miast.

Analizując stopień zaufania do mediów, zauważyć można powiązania z poprzednimi opiniami. Otóż, zdaniem mieszkańców dużych miast, najmniejszej sile oddziaływania Internetu odpowiada najniższy stopień zaufania do niego oraz najwyższe domniemanie możliwości pojawiania się złych skutków korzystania z zamieszczonych w nim informacji, co różni tę grupę osób w sposób statystycznie istotny od mieszkańców mniejszych miast oraz wsi. Programy telewizyjne oraz radiowe cieszą się największą wiarygodnością wśród osób zamieszkujących wieś oraz duże miasta, różniąc je pod tym względem od mieszkańców małych miast w sposób statystycznie istotny.

Najbardziej krytycznymi co do przydatności, a przede wszystkim jakości informacji, byli mieszkańcy dużych miast, którzy jednocześnie najsilniej podkreślali zbyt małą liczbę prozdrowotnych kampanii społecznych, do których mogli mieć duże zaufanie, jako najbardziej sprawdzonych pod względem merytorycznym źródeł informacji.

Kolejnym przedmiotem badań była ocena częstotliwości korzystania z poszczególnych rodzajów mediów i jeśli chodzi o Internet, fora internetowe i telewizję, to wskazywali na nie w podobnym nasileniu mieszkańcy wsi i miast do 50 tys. mieszkańców, różniąc się pod tym względem w sposób statystycznie istotny od osób zamieszkujących miasta powyżej 50 tys. mieszkańców. Opinie te korelują z poprzednio wyrażonymi ocenami dotyczącymi siły oddziaływania i zaufania do mass mediów jako źródeł informacji w zakresie prozdrowotnego stylu życia. Można stąd także wnosić, że braki infrastrukturalne mniejszych miejscowości w tym zakresie zostają w pewnym stopniu niwelowane na tej drodze. Mieszkańcy największych miast najczęściej poszukiwali informacji o zdrowym stylu życia w prasie, co znalazło już swój wyraz w ich opinii dotyczącej siły promocyjnej tego medium i różniło się zarówno od osób zamieszkujących wsie, jak i mniejsze miasta. Korzystanie z porad w mediach przez osoby z najbliższego otoczenia pod względem statystycznym w badanych grupach osób było podobne. 
Tabela 4. Miejsce zamieszkania respondentów a ich opinie o stopniu oddziaływania i zaufania do mediów w zakresie upowszechniania zdrowego stylu życia

* - istotność przy prawdopodobieństwie $\mathrm{p}=0,05$

** - istotność przy prawdopodobieństwie $\mathrm{p}=0,01$

\begin{tabular}{|c|c|c|c|c|c|c|}
\hline \multirow{3}{*}{$\begin{array}{l}\text { Opinie respondentów względem } \\
\text { mediów }\end{array}$} & \multicolumn{3}{|c|}{$\begin{array}{l}\text { Średnie rangi dla } \\
\text { opinii wśród } \\
\text { respondentów }\end{array}$} & \multicolumn{3}{|c|}{$\begin{array}{l}\text { Ocena różnic rang między } \\
\text { grupami respondentów wg } \\
\text { zamieszkania }\end{array}$} \\
\hline & \multirow{2}{*}{ wieś } & \multicolumn{2}{|c|}{$\begin{array}{c}\text { miasta wg } \\
\text { mieszk. }\end{array}$} & & \multirow{2}{*}{\begin{tabular}{|l} 
wieś a \\
m.> \\
50tys.
\end{tabular}} & \\
\hline & & $\begin{array}{l}<50 \\
\text { tys. }\end{array}$ & & & & \\
\hline \multicolumn{7}{|l|}{$\begin{array}{l}\text { Siła promocyjnego oddziaływania } \\
\text { mediów: }\end{array}$} \\
\hline -Internetu & 61,9 & 73,6 & 35,2 & 0,38 & $0,00^{* *}$ & $0,00^{* *}$ \\
\hline - telewizji & 69,7 & 47,3 & 59,1 & $0,01^{*}$ & 0,54 & 0,32 \\
\hline - prasy & 46,9 & 51,5 & 73,4 & 1,0 & $0,00^{* *}$ & $0,00^{* *}$ \\
\hline - radia & 62,1 & 39,0 & 75,0 & $0,00^{* *}$ & 0,31 & $0,00^{* *}$ \\
\hline \multicolumn{7}{|l|}{$\begin{array}{l}\text { Stopień zaufania do mediów wg ich } \\
\text { rodzajów: }\end{array}$} \\
\hline - Internet & 58,7 & 71,6 & 40,2 & 0,28 & 0,06 & $0,00^{* *}$ \\
\hline $\begin{array}{l}\text { - możliwość złych skutków } \\
\text { wykorzystania } \\
\text { wiedzy uzyskanej poprzez Internet }\end{array}$ & 48,7 & 46,3 & 78,0 & 1,0 & $0,00^{* *}$ & $0,00^{* *}$ \\
\hline - telewizja & 66,3 & 44,1 & 65,6 & $0,01^{*}$ & 1,0 & $0,00^{* *}$ \\
\hline - radio & 65,2 & 41,2 & 69,3 & $0,00^{* *}$ & 1,0 & $0,00^{* *}$ \\
\hline Media a jakość informacji & 61,3 & 64,8 & 45,8 & 1,0 & 0,15 & $0,03^{*}$ \\
\hline Media a przydatność informacji & 61,6 & 62,8 & 48,0 & 1,0 & 0,26 & 0,13 \\
\hline $\begin{array}{l}\text { Wystarczalność liczby prozdrowotnych } \\
\text { kampanii społecznych }\end{array}$ & 63,4 & 71,6 & 36,2 & 0,86 & $0,00 * *$ & $0,00 * *$ \\
\hline \multicolumn{7}{|l|}{ Częstość korzystania z porad w mediach: } \\
\hline -Internetu & 71,1 & 65,8 & 36,5 & 1,0 & $0,00^{* *}$ & $0,00^{* *}$ \\
\hline -for internetowych & 62,1 & 70,6 & 38,5 & 0,81 & $0,00^{* *}$ & $0,00^{* *}$ \\
\hline - telewizji & 53,2 & 71,5 & 44,9 & 0,06 & 0,88 & $0,00^{* *}$ \\
\hline - prasy & 40,9 & 54,5 & 75,0 & 0,23 & $0,00^{* *}$ & $0,02^{*}$ \\
\hline $\begin{array}{l}\text { Korzystanie z porad w mediach przez } \\
\text { osoby } \\
\text { z najbliższego otoczenia }\end{array}$ & 53,9 & 65,9 & 50,8 & 0,35 & 1,0 & 0,12 \\
\hline
\end{tabular}

Źródło: Obliczenia własne

\section{Poziom wykształcenia respondentów a ich opinie o roli mediów jako źródła informacji w zakresie zdrowego stylu życia}

Jako ostatnią podstawę analizy ocen mediów jako źródła informacji dotyczących zdrowego stylu życia przyjęto wykształcenie respondentów, tj. ukończoną szkołę zawodową, średnią lub wyższą (tab. 5). 
Tabela5. Wykształcenie respondentów a ich opinie o stopniu oddziaływania i zaufania do mediów w zakresie upowszechniania zdrowego stylu życia

"- istotność przy prawdopodobieństwie $\mathrm{p}=0,05$

** - istotność przy prawdopodobieństwie $\mathrm{p}=0,01$

\begin{tabular}{|c|c|c|c|c|c|c|}
\hline \multirow{3}{*}{$\begin{array}{l}\text { Opinie respondentów względem } \\
\text { mediów }\end{array}$} & \multicolumn{3}{|c|}{$\begin{array}{l}\text { Średnie rangi dla } \\
\text { opinii wśród } \\
\text { respondentów }\end{array}$} & \multicolumn{3}{|c|}{$\begin{array}{l}\text { Ocena różnic rang między } \\
\text { grupami respondentów wg } \\
\text { wykształcenia }\end{array}$} \\
\hline & \multirow{2}{*}{ zawod. } & \multirow{2}{*}{$\begin{array}{l}\text { śred } \\
\text { nie }\end{array}$} & \multirow{2}{*}{ wyższe } & & zawod. a & średnie a \\
\hline & & & & średnie & wyższe & wyższe \\
\hline \multicolumn{7}{|l|}{$\begin{array}{l}\text { Siła promocyjnego oddziaływania } \\
\text { mediów: }\end{array}$} \\
\hline -Internetu & 28,8 & 64,1 & 79,9 & $0,00^{* *}$ & $0,00^{* * *}$ & 0,11 \\
\hline - telewizji & 61,2 & 60,1 & 50,5 & 1,0 & 0,5 & 0,6 \\
\hline - prasy & 78,5 & 55,5 & 37,7 & $0,00^{* *}$ & $0,00^{* *}$ & 0,06 \\
\hline - radia & 79,8 & 48,1 & 45,2 & $0,00^{* *}$ & $0,00^{* *}$ & 1,0 \\
\hline \multicolumn{7}{|l|}{$\begin{array}{l}\text { Stopień zaufania do mediów wg ich } \\
\text { rodzajów: }\end{array}$} \\
\hline - Internet & 28,8 & 65,0 & 78,9 & $0,00^{* *}$ & $0,00^{* * *}$ & 0,2 \\
\hline $\begin{array}{l}\text { - możliwość złych skutków } \\
\text { wykorzystania } \\
\text { wiedzy uzyskanej poprzez Internet }\end{array}$ & 77,4 & 49,8 & 45,7 & $0,00^{* *}$ & $0,00^{* *}$ & 1,0 \\
\hline -telewizja & 81,2 & 57,0 & 33,0 & $0,00^{* *}$ & $0,00^{* * *}$ & $0,00^{* *}$ \\
\hline -radio & 80,0 & 56,4 & 35,0 & $0,00^{* *}$ & $0,00^{* * *}$ & $0,01^{*}$ \\
\hline Media a jakość informacji & 43,2 & 57,1 & 73,0 & 0,2 & $0,00^{* * *}$ & 0,11 \\
\hline Media a przydatność informacji & 39,0 & 57,5 & 77,14 & $0,04^{*}$ & $0,00^{* *}$ & $0,03^{*}$ \\
\hline $\begin{array}{l}\text { Wystarczalność liczby prozdrowotnych } \\
\text { kampanii społecznych }\end{array}$ & 39,2 & 63,8 & 69,2 & $0,00^{* *}$ & $0,00^{* *}$ & 1,0 \\
\hline \multicolumn{7}{|l|}{$\begin{array}{l}\text { Częstość korzystania z porad } \\
\text { w mediach: }\end{array}$} \\
\hline - Internetu & 27,9 & 70,1 & 73,7 & $0,00^{* *}$ & $0,00^{* *}$ & 1,0 \\
\hline -for internetowych & 28,7 & 68,4 & 74,8 & $0,00^{* *}$ & $0,00^{* * *}$ & 1,0 \\
\hline - telewizji & 34,4 & 63,3 & 75,0 & $0,00^{* *}$ & $0,00^{* *}$ & 0,37 \\
\hline - prasy & 67,4 & 38,7 & 69,6 & $0,00^{* *}$ & 1,0 & $0,00^{* *}$ \\
\hline $\begin{array}{l}\text { Korzystanie z porad w mediach przez } \\
\text { osoby } \\
\text { z najbliższego otoczenia }\end{array}$ & 44,5 & 54,2 & 75,2 & 0,6 & $0,00^{* *}$ & $0,02^{*}$ \\
\hline
\end{tabular}

\section{Źródło: Obliczenia własne}

Na podstawie wyników badań można stwierdzić, że na coraz to większe (i statystycznie różniącym się poziomie) oddziaływanie Internetu na upowszechnianie zdrowego stylu życia wskazywali kolejno absolwenci szkół zawodowych, a następnie średnich i wyższych. Kolejność ta była odwrotna w przypadku oceny siły wpływu prasy i radia, przy czym we wszystkich tych przypadkach tylko różnice opinii osób z wykształceniem średnim i wyższym nie różniły się w sposób udowodniony statystycznie. Siła oddziaływania telewizji nie różniła w sposób statystycznie istotny osoby z różnym wykształceniem. 
Kolejnym celem badań była ocena stopnia zaufania do informacji dotyczących zdrowego stylu życia podawanych w mediach. Analiza wyników ankietyzacji wykazała, że Internet cieszył się największą wiarygodnością wśród osób z wyższym i średnim wykształceniem, różniąc je w sposób statystycznie istotny od absolwentów szkół zawodowych i korelując ponownie z uzyskanymi poprzednio wynikami dotyczącymi opinii o sile oddziaływania tego medium. Jednocześnie osoby z wykształceniem zawodowym wykazały różniącą ich od pozostałych grup osób statystycznie udowodnioną odmienność poglądów, polegającą na domniemaniu większej możliwości powstania złych skutków wykorzystania wiedzy uzyskanej przez Internet. Programy telewizyjne i radiowe cieszyły się malejącym i różniącym się statystycznie poziomem zaufania wśród respondentów w miarę wzrostu poziomu ich wykształcenia.

Opinia o przydatności informacji o zdrowym stylu życia rosła w sposób statystycznie istotny wraz ze wzrostem wykształcenia osób. Podobną tendencję wykazała ocena jakości tych przekazów, z tym, że statystycznie istotna różnica w tym zakresie wystąpiła tylko między osobami z wykształceniem wyższym i zawodowym.

Liczba prozdrowotnych kampanii społecznych okazała się niewystarczająca dla osób z wykształceniem zawodowym, co różniło je w sposób statystycznie istotny od opinii wyrażanych w tym względzie przez absolwentów szkół średnich i wyższych. Zauważyć można także prawidłowość polegającą na tym, że we wszystkich analizowanych przypadkach liczbę prowadzonych kampanii społecznych uznawały za wystarczającą te grupy osób, które najczęściej korzystały z Internetu, darząc go najczęściej zaufaniem i uznając dużą siłę jego oddziaływania.

Rozkład częstości korzystania z porad przedstawianych w mediach wskazuje, że największe zainteresowanie Internetem i forami internetowymi wykazywały osoby z wykształceniem wyższym i średnim, różniąc się pod tym względem w sposób statystycznie istotny od absolwentów szkół zawodowych, co koreluje w sposób dodatni z przekonaniami wyrażonymi poprzednio, a dotyczącymi opinii co do siły promocyjnego oddziaływania tych środków przekazu. Oglądalność programów telewizyjnych dotyczących zdrowego stylu życia także była wyższa wśród osób po studiach i z wykształceniem średnim, różniąc się z uwagi na to zachowanie w sposób statystycznie istotny od absolwentów szkół zawodowych. Z kolei prasa cieszyła się najmniejszą popularnością wśród absolwentów szkół średnich, co różniło ich w sposób statystycznie istotny od osób z wykształceniem zawodowym i wyższym. Korzystanie z porad w mediach przez osoby z najbliższego otoczenia było najwyższe w grupie respondentów z wykształceniem wyższym, różniąc ich pod tym względem od pozostałych badanych. Zwrócić należy uwagę na to, że wykazane tu zależności są podobne do tych stwierdzonych poprzednio dla podgrupy osób młodszych, co wiąże się z faktem, że osoby te posiadały jednocześnie wyższy poziom wykształcenia od osób starszych.

\section{Podsumowanie i wnioski}

Przedstawione pilotażowe badania miały na celu analizę opinii dotyczących różnych rodzajów mass mediów, pod względem siły ich oddziaływania, stopnia zaufania do 
nich oraz częstości korzystania z nich jako źródła informacji w zakresie zdrowego stylu życia. Ocenę tych poglądów, ze względu na jakościowy charakter zmiennych, przeprowadzono posługując się statystyką testu Kruskala-Wallisa. Pozwoliła ona uwzględnić, jako determinanty tych opinii, wiek, płeć, miejsce zamieszkania i wykształcenie respondentów. Przeprowadzona analiza wykazała silne uwarunkowanie opinii ankietowanych osób z uwagi na przyjęte determinanty. Zauważyć można było także dużą zbieżność poglądów wyrażanych przez wyodrębnione grupy badanych osób dotyczących siły oddziaływania, stopnia zaufania i częstości korzystania z poszczególnych rodzajów mediów.

Najbardziej wyraźne związki w powyższym zakresie stwierdzono względem Internetu i forów internetowych, na które jako najważniejsze wskazywały osoby młodsze, kobiety, mieszkańcy wsi i mniejszych miast oraz osoby z wyższym wykształceniem. Trzeba tu jednak zwrócić uwagę na fakt, że najwięksi zwolennicy Internetu, w przeciwieństwie do pozostałych respondentów, wykazywali jednocześnie wyższą tolerancję względem możliwości wystąpienia złych skutków korzystania z wiedzy prezentowanej w Internecie, co świadczy o ich zmniejszonym krytycyzmie wobec tego wygodnego i coraz to łatwiej dostępnego medium. Ponadto ta grupa osób uznawała za wystarczającą liczbę prowadzonych kampanii społecznych na rzecz zdrowego stylu życia.

Prasę, jako medium upowszechniające korzystny dla kondycji zdrowotnej styl życia przedkładali respondenci starsi, mężczyźni, osoby z wykształceniem wyższym i średnim oraz mieszkańcy wsi. Z kolei jakość i przydatność informacji przekazywanych przez mass media w powyższym zakresie w najwyższym stopniu ceniły osoby młodsze, mieszkańcy wsi i mniejszych miast oraz absolwenci szkół wyższych.

Respondenci potwierdzili opinię, że media mają obecnie ogromny wpływ na styl życia, kształtują nawyki, mobilizują do zmian, dostarczają wiedzę oraz edukują. Duża grupa badanych jest zdania, że informacje o zdrowiu propagowane poprzez mass media, będąc skuteczną metodą zachowania zdrowia, są wiarygodne, łatwo dostępne, co świadczy z kolei o wzroście świadomości społecznej na temat zdrowia oraz coraz szerszym zainteresowaniu tematyką prozdrowotną.

Wnioski płynące $\mathrm{z}$ analizowanego badania skonkretyzować można do następujących:

1. Media w obecnych czasach stanowią jedno z głównych źródeł pozyskiwania informacji, przez dużą część respondentów, na temat zdrowia oraz działań profilaktycznych zmierzających do jego zachowania i poprawy.

2. Informacje o zdrowiu przekazywane przez środki komunikacji społecznej, oceniane są jako przydatne i wiarygodne źródło dla dużej części odbiorców, którzy nie szukają potwierdzenia prawdziwości tych informacji w innych źródłach.

3. Środki komunikacji społecznej wpływają na zasób posiadanej wiedzy z zakresu edukacji i promocji zdrowia, a tym samym przyczyniają się do kształtowania zdrowego stylu życia w społeczeństwie.

4. Trudno znaleźć w literaturze fachowej informacje potwierdzające efektywność oddziaływania mass mediów na zachowania odbiorców w sferze zdrowego stylu życia, gdyż badania takie są prowadzone od niedawna, a określenie ich oddziały- 
wania jest procesem długotrwałym, wymagającym wielorakich badań oraz analiz statystycznych.

5. Treść programów o charakterze edukacyjnym i promujących zdrowie, posiada często formę popularno-naukową i rozrywkową, bowiem ma zaciekawić tematem i przekazać dane treści w sposób prosty, ciekawy i zrozumiały.

Dla każdego człowieka zdrowie jest najważniejszą i najcenniejszą wartością. Media, jako technologie i formy obiegu informacji w społeczeństwie, stały się niezbędnym składnikiem współczesnego życia społecznego. Intensywny rozwój techniki spowodował, iż są one ważnym źródłem informacji o zdrowiu dla przeciętnego człowieka, a promocja zdrowia jest ważnym zagadnieniem poruszanym przez społeczeństwo. Popularne mass media takie, jak: telewizja, Internet, prasa, radio, wywierają silny wpływ edukacyjny na zachowania zdrowotne, będąc znaczącym czynnikiem funkcjonowania każdego społeczeństwa. Wpływają one na postawy, działania i wiedzę prozdrowotną, dlatego w celu poprawy skuteczności edukacji zdrowotnej niezbędne jest współdziałanie ze środkami masowego przekazu. Cechą mass mediów jest ich powszechność, ogólnodostępność, a tym samym możliwość większej perswazji.

Znaczenie mass mediów jako nowoczesnego narzędzia mającego na celu osiągnięcie i utrzymanie zdrowia, a także rola edukacyjno-wychowawcza środków masowego przekazu została uznana i znalazła odzwierciedlenie w Narodowym Programie Zdrowia [2007] oraz w Ustawie o Radiofonii i Telewizji [1992].

Media wciąż ewoluują, zmieniają się, dostosowując swoją ofertę do oczekiwań odbiorców, którzy w miarę wzrostu świadomości stają się jednocześnie coraz bardziej wymagający. Dotyczy to również informacji o zdrowiu, których nacisk w dziedzinie profilaktyki prozdrowotnej powinien być położony na ulepszenie sposobów umożliwiających ich skuteczniejszy i szerszy odbiór. Siła oddziaływania mediów na odbiorcę coraz bardziej interesuje rosnącą liczbę badaczy, którzy starają się zrozumieć, jak mass media wpływają na społeczeństwo oraz na poszczególne jednostki [Kozłowska, 2006].

Podjęty problem badawczy stanowi jedynie mały przyczynek do dalszych pogłębionych badań, które powinny być prowadzone w zakresie roli i oddziaływania mediów w upowszechnianiu zdrowego stylu życia współczesnego społeczeństwa.

\section{BIBLIOGRAFIA:}

Aczel A. D. (2000), Statystyka w zarządzaniu. Pełny wykład, PWN, Warszawa, pp. 731-735.

Goban-Klas T. (2002), Media i komunikowanie masowe. Teoria i analizy prasy, radia, telewizji i Internetu, Wydawnictwo Naukowe PWN, Kraków, p. 49.

Gugała B., Boratyn-Dubiel L., Chmiel Z. (2010), Internet jako narzędzie wiedzy o zdrowiu, „Medycyna Ogólna”, 16 (2), pp. 266-273.

Kozłowska A. (2006), Oddziaływanie mass mediów, Szkoła Główna Handlowa w Warszawie, Oficyna Wydawnicza, Warszawa, p. 12. 
Szymczuk E., Zajchowska J., Dominik A., Makara-Studzińska M., Zwolak A., Daniluk J. (2011), Media jako źródło wiedzy o zdrowiu, „Medycyna Ogólna i Nauk o Zdrowiu”, 17 (4), pp. 165-168.

Syrkiewicz-Świtała M., Holecki T., Wojtynek E. (2014), Znaczenie mass mediów w promocji zdrowia, „Medycyna Ogólna i Nauk o Zdrowiu”, 20 (2), pp. 171-176.

Turbiasz A., Kadłubowska M., Kolonko J., Bąk E. (2010), Rola mediów w promocji zdrowia, „Problemy Pielęgniarstwa”, 18(2), pp. 239-241.

\section{LITERATURA UZUPEENIAJĄCA}

Narodowy Program Zdrowia na lata 2007-2015. Załącznik do Uchwały RM nr $90 / 2007$, http://www.mz.gov.pl/__data/assets/pdf_file/0020/12494/zal_urm_np z_90_15052007p.pdf, (dostęp: 25.09.2015).

Ustawa o Radiofonii i Telewizji. Dz. U. z dnia 29.12.1992 r., rozdz. 4, art. 21 pkt 1, 2, 7a, 7b, 10. http://isap.sejm.gov.pl/DetailsServlet?id=WDU19930070034, (dostęp: 25.09.2015).

\section{O AUTORACH:}

Jan Krupa - prof. nadzw. dr hab. inż. - kierownik Katedry Turystyki i Rekreacji w Wyższej Szkole Informatyki i Zarządzania, na Wydziale Medycznym, kierunku Turystyka i Rekreacja. Autor i współautor ponad 250 pozycji naukowych, 4 książek oraz redaktor 11 monografii. W kręgu zainteresowań znajdują się, m.in. problematyka żywienia człowieka, ekologia i ochrona środowiska, turystyka zdrowotna i kulinarna oraz dziedzictwo kulturowe w turystyce.

Andrzej Mantaj dr inż. - Katedra Metod Ilościowych w Ekonomii na Wydziale Administracji i Nauk Społecznych Wyższej Szkoły Informatyki i Zarządzania w Rzeszowie. Autor i wspólautor około 50 publikacji naukowych, dotyczących głównie problematyki ekonomicznej.

Sławomir Gawroński - prof. nadzw. dr hab. - politolog, medioznawca, dziekan Wydziału Administracji i Nauk Społecznych Wyższej Szkoły Informatyki i Zarządzania w Rzeszowie. Autor, współautor i redaktor około 100 publikacji poświęconych głównie komunikacji marketingowej i public relations. Naukowo zajmuje się również problematyką oddziaływania mediów masowych, content marketingiem i brandingiem narodowym.

KONTAKT: sgawronski@wsiz.rzeszow.pl 